\title{
CHIMERIC ANTIGEN RECEPTOR EXPRESSION IN NATURAL KILLER CELL LINE NK-92 BY TRANSDUCTION WITH LENTIVIRAL PARTICLES PSEUDOTYPED WITH THE SURFACE GLYCOPROTEINS OF THE MEASLES VIRUS VACCINE STRAIN
}

\author{
Kravchenko YE, Gagarinskaya DI, Frolova El, Chumakov SP $\bowtie$ \\ Shemyakin-Ovchinnikov Institute of Bioorganic Chemistry of the Russian Academy of Sciences, Moscow
}

\begin{abstract}
Cancer immunotherapy with T-cells that carry chimeric antigen receptors is currently on cutting edge of modern oncology. Autotransplantation of T-lymphocytes with chimeric receptor specific for certain tumor antigen proves to be clinically effective, but costly. Linear carriers of chimeric antigen receptors based on natural killer NK-92 cell culture may be an affordable alternative, however, this culture is resistant to lentiviral transduction. Recently, lentiviral vectors, pseudotyped with surface glycoproteins of the measles virus vaccine strain, have recently been successfully applied for transduction of primary immune cells. The aim of the work was to assess the efficiency of transduction of NK-92 cells with lentivirus vectors, pseudotyped with measles $\mathrm{F}$ and $\mathrm{H}$ surface glycoproteins, as well as to establish optimal conditions for selection of NK-92 transduced with the chimeric receptor against CD20 and to evaluate the culture's cytotoxic potential. The results showed that the maximum infectious titer is achieved using the $\mathrm{H} \triangle 18$ variant in combination with $\mathrm{F} \triangle 30$, and the use of the TBK1/IKKE inhibitor BX795 results in additional 3-fold increase in the infectious titer. CAR-expressing NK-92 were able to suppress the proliferation of CD20+ cell line Raji in lower effector-to-target ratios than unmodified NK-92.
\end{abstract}

Keywords: cellular immunotherapy, chimeric antigen receptors, CAR, lentiviral vectors, natural killer cells, linear cellular carriers, pseudotyping with measles glycoproteins

Funding: this work was funded by MESR (project code RFMEFI60716X0156).

$\varangle$ Correspondence should be addressed: Stepan P. Chumakov Miklukho-Maklaya 16/10, Moscow, 117997; hathkul@gmail.com

Received: 27.11.2018 Accepted: 20.12.2018

DOI: $10.24075 /$ brsmu.2018.091

\section{ЭКСПРЕССИЯ ХИМЕРНОГО АНТИГЕННОГО РЕЦЕПТОРА В НАТУРАЛЬНЫХ КИЛЛЕРАХ ЛИНИИ NК-92 ПУТЕМ ТРАНСДУКЦИИ ЛЕНТИВИРУСНЫМИ ЧАСТИЦАМИ, ПСЕВДОТИПИРОВАННЫМИ ПОВЕРХНОСТНЫМИ ГЛИКОПРОТЕИНАМИ ВАКЦИННОГО ШТАММА ВИРУСА КОРИ}

\author{
Ю. Е. Кравченко, Д. И. Гагаринская, Е. И. Фролова, С. П. Чумаков \\ Институт биоорганической химии имени М. М. Шемякина и Ю. А. Овчинникова РАН, Москва
}

\begin{abstract}
Клеточная иммунотерапия с использованием химерных антигенных рецепторов (ХАР) является одним из перспективных направлений развития современной онкологии. Собственные Т-лимфоциты пациента с приданной специфичностью в отношении неоантигенов опухолей за счет экспрессии ХАР демонстрируют клиническую эффективность, однако стоимость такой терапии чрезвычайно высока. В качестве более доступной альтернативы могут быть использованы унифицированные носители ХАР на основе линии клеток натуральных киллеров NK-92. Эта культура отличается устойчивостью к лентивирусной трансдукции; однако для трансдукции первичных иммунных клеток недавно начали успешно применять лентивирусные векторы, псевдотипированные поверхностными гликопротеинами вакцинного штамма вируса кори. Целью работы было определить эффективность трансдукции клеток NK-92 лентивирусами, псевдотипированными гликопротеинами F и H вируса кори, а также условия селекции NK-92, трансдуцированных химерным рецептором против CD20, и оценить их цитотоксическое действие. Результаты исследования показали, что максимальный трансфекционный титр достигается при использовании варианта белка H (H $\triangle 18)$ в сочетании с вариантом белка F (FA30), а применение BX795 (ингибитора TBK1/IKKع) дополнительно позволяет добиться трехкратного увеличения инфекционного титра. ХАР-экспрессирующие клетки NK-92 оказались способными подавлять пролиферацию CD20+-клеток линии Raji в меньшей дозе, по сравнению с немодифицированными клетками NK-92.
\end{abstract}

Ключевые слова: клеточная иммунотерапия, химерные антигенные рецепторы, ХАР, лентивирусные векторы, натуральные киллеры, линейные клеточные носители, псевдотипирование, гликопротеины кори

Финансирование: работа выполнена при финансовой поддержке Министерства образования и науки РФ, уникальный код проекта RFMEFI60716X0156.

$\bowtie$ Для корреспонденции: Степан Петрович Чумаков

ул. Миклухо-Маклая, 16/10, г. Москва, 117997; hathkul@gmail.com

Статья получена: 27.11.2018 Статья принята к печати: 20.12.2018

DOI: $10.24075 /$ vrgmu.2018.091 
Cellular immunotherapy is one of the key areas of development of modern oncology. By introducing into the patient's bloodstream the immune cells that target tumor antigens it may be possible to achieve high specificity of action and treatment efficacy, with a low incidence of undesirable effects [1]. In research and clinical trials, the most frequent vehicle is the patient's own cytotoxic T-lymphocytes with induced specificity for a particular tumor antigen or their combination. These modifications are performed by expressing a chimeric antigen receptor (CAR), consisting of several intracellular signaling domains for T-lymphocyte activation and an extracellular region that recognizes a tumor antigen [2]. For the introduction of constructs expressing CAR, chemical transfection of cells [3], electroporation [4], or transduction with viral vectors [5] is used most frequently. After transduction, the cell population can be expanded in culture to obtain the required number of cells. Treatment regimens based on CAR-T cells demonstrate good clinical efficacy, but the cost of therapy is often extremely high, which is due to the requirement for production of a personalized T-cell population for each patient. Another factor which constrains the prospects for the massive adoption of CAR-T cells in clinical practice is the limited availability of the patient's own T-lymphocytes in patients with late stages of cancer. It is possible to overcome these drawbacks, but this will require a significant improvement in the field of cell culturing and production.

Natural killer cell lines that carry chimeric antigen receptors may be considered as a less expensive, universal and more affordable alternative than CAR-T cell preparations. Out of 11 established and widely available natural killer lines that were obtained from patients with various lymphoproliferative diseases, only two - KHYG-1 [6] and NK-92 [7] — have a pronounced ability to suppress the growth of tumor cells due to intrinsic cytotoxic activity, in the absence of expression of Fc receptors [8]. Both cell lines are able to proliferate in the presence of IL2 in the culture medium, NK-92, in particular, was shown to be able to selectively destroy K-562 lymphoma cells cultured in a mixture with normal peripheral mononuclear cells. NK-92 cells were also able to maintain cytotoxicity after gamma irradiation with a dose of 10 Gray, without being proliferatively active, which allows them to be used for the treatment of cancer [9].

To enhance the cytotoxic properties of NK-92, genetically modified variants have been created that express either their own IL2, IL15 [10]; or additional receptors - CD16, for targeting tumor cells with antibodies, or CAR, for direct recognition of tumor antigens [11]. Functionally, CAR-expressing NK-92 are similar to CAR-T cells, while the cost of therapy may be substantially reduced - the cell line can be expanded in bulk quantities; and preliminary procedures for treating a patient will consist only in defrosting the ready-to-use aliquot [12]. In addition to being used for therapy, NK-92 cells can serve as a platform for testing and development of various types of chimeric receptors in vitro and in vivo. The main obstacle while manipulating with cells of this line is its sensitivity to cultivation conditions, as well as high resistance to lentiviral transduction: viral vectors pseudotyped with VSV G-protein do not efficiently transduce NK-92 cells, and as the amount of viral particles in the medium increases, the cells quickly lose viability [13]. For lentiviral transduction of peripheral T-lymphocytes and immune cells of myeloid lineage, lentiviral vector particles pseudotyped with surface glycoproteins of the measles virus vaccine strain have been recently developed [14]. Compared to conventional lentiviral vectors pseudotyped with VSV G-protein, they have shown to posess much higher ability to transduce immune cells without either stimulating cell division, or changing their phenotype or the profile of secreted cytokines [15]. The aim of this work was to determine the efficicacy of transduction of NK92 cells with lentiviruses, pseudotyped $\mathrm{F}$ and $\mathrm{H}$ glycoproteins of the measles virus, as well as to determine the conditions for isolation and purification of NK-92 cells transduced with a chimeric receptor directed against the CD20 antigen, and to assess their cytotoxic potential.

\section{METHODS}

\section{Plasmids and constructs}

For packaging of lentiviral vectors, pseudotyped with VSV-G, packaging plasmids psPAX2 (contains lentiviral structural proteins) and pMD2-G (encodes VSV G-protein) were used. Both plasmids were kindly provided by Didier Trono (Addgene plasmid \# 12260; http://n2t.net/addgene:12260; RRID: Addgene_12260 and Addgene plasmid \# 12259; http://n2t.net/addgene:12259; RRID: Addgene_12259). For pseudotyping with measles glycoproteins, instead of pMD2-G, the plasmid pMD2-F $\triangle 30$ was used, which encodes a fragment of the F protein of the measles virus of the ESC vaccine strain with a cytoplasmic domain truncated by 30 amino acids. For preparation of measles virus cDNA and subsequent amplification of target genome fragment by PCR, were used primers Fdelta30 dir ECORI (AGAGGAATTCACCACCATGTCC ATCATGGGTCTCAAGGTGAACGTCTCTG) and Fdelta30 rev ECORI (AGAGAGAATTCTCAACGCCCCCTGCAGCAACATA TTAAAGCG), cloning was performed to the vector pMD2-G by EcoRI sites. In combination with pMD2-F $\triangle 30$, the plasmid pCG-Hc $\triangle 18$ was used, provided by Jacob Reiser (Addgene plasmid \# 84817; http://n2t.net/addgene:84817; RRID: Addgene_84817), as well as its variants, with truncation of 24 $\mathrm{N}$-terminal amino acids of the $\mathrm{H}$ protein (pCG-Hc $\triangle 24)$, or with addition of 4 alanine residues (pCG-4AHc $\triangle 24$ ). The plasmids were produced by cloning the original $H$ protein fragment amplified with primers Hd24 BamHI dir (AGAGAGGGATCCAG GGTGCAAGATCATCCACAATGAACCGGGAGCACCTGATG) and $H$ rev (CTGATGTCTATTCACACTAGTACAAAC), or with primers Hd24 4a BamHI dir (AGAGAGGGATCCAGGGTGCA AGATCATCCACAATGGCCGCTGCAGCCAACCGGGAGCAC CTGATG) and $H$ rev, respectively, by restriction sites BamHI and Spel. Lentiviral vectors pLCMV-tagRFP-puro (containing sequence of red fluorescent protein tagRFP (Evrogen; Russia) under the control of a cytomegalovirus promoter) and pLSF-@ CD20-229-tagRFP containing the sequence of 3-rd gen chimeric receptor against the surface antigen CD20 (CD8 leader peptide, ScFv from HB-9645 hybridoma clone, DYKDDDDK epitope, 229 amino acid linker region, CD28 transmembrane domain, and CD28, CD137, and CD3z signaling domains) and tagRFP, with polycistronic expression using the T2A signal sequence under the control of the SFFV promoter.

\section{Cell cultures}

For lentivirus packaging, the HEK-293T cell line was used, cells were cultured in DMEM-F12 (PAA; Austrian) medium with addition of fetal calf serum up to $10 \%, 2 \mathrm{mM}$ alanyl-glutamine (PanEco; Russia), $20 \mathrm{mM} \mathrm{HEPES}$ and $100 \mu \mathrm{g} / \mathrm{ml}$ penicillin and streptomycin.

Cultivation of NK-92 was carried out in RPMl-1640 medium (PAA; Austrian) with the addition of fetal calf serum and horse serum up to $20 \%$ in equal proportions, $2 \mathrm{mM}$ alanyl-glutamine (PanEco; Russia), 20 mM HEPES, 0.2 mM inositol, $0.1 \mathrm{mM}$ 
2-mercaptoethanol, $1 \mu \mathrm{M}$ water-soluble hydrocortisone (Sigma; USA), $20 \mu \mathrm{M}$ folic acid and recombinant IL 2 at a final concentration of $100 \mu \mathrm{g} / \mathrm{ml}$.

Raji cells (Burkitt's lymphoma) (ATCC; USA) expressing GFP fluorescent protein were used as targets for CAR-expressing NK-92 cells. The cells were cultivated in RPMl-1640 medium (PanEco; Russia) with the addition of fetal calf serum up to $10 \%$, $2 \mathrm{mM}$ alanyl-glutamine (PanEco; Russia), $20 \mathrm{mM}$ HEPES and $100 \mu \mathrm{g} / \mathrm{ml}$ penicillin and streptomycin. All cells were cultured in $5 \% \mathrm{CO}_{2}$ conditions at $37^{\circ} \mathrm{C}$.

\section{Transfection and viral transduction}

Transfection was carried out on 6-well plates in OptiMEM medium (Invitrogen; USA) using polyethyleneimine 25kDA (PEI-25, Polysciences; USA) on HEK-293T cells at 40-60\% confluence seeded the day before the procedure.
For lentiviral vectors pseudotyped with VSV-G, a mixture of the following plasmids was prepared: pLCMV-tagRFPpuro containing marker protein $(1.5 \mu \mathrm{g})$, psPAX2 $(0.9 \mu \mathrm{g})$ and pMD2-G $(0.6 \mu \mathrm{g})$ in the ratio of $5: 3: 2$, respectively. For pseudotyping with measles glycoproteins, plasmids pLCMVtagRFP-puro or pLSF-@CD20-229-tagRFP (0.9 $\mu \mathrm{g})$, psPAX2 $(0.9 \mu \mathrm{g})$, pMD2-F $\triangle 30(0.79 \mu \mathrm{g})$, pCG-Hc $\Delta 18(0.11 \mu \mathrm{g})$ or its variations $\mathrm{pCG}-\mathrm{Hc} \Delta 24(0.11 \mu \mathrm{g})$ and $\mathrm{pCG}-4 \mathrm{AHc} \Delta 24(0.11$ $\mu \mathrm{g})$ were used in a ratio of $8: 8: 7: 1$. After a three-hour incubation of the cells with the transfection mixture, the medium was replaced with RPMI-1640 containing the serum replacement (Serum Replacement Solution, PeproTech; USA), 2 mM alanyl-glutamine (PanEco; Russia), 20 mM HEPES and 4 $\mathrm{mM}$ caffeine, in which HEK-293T were incubated for 24 hours for the production of viral particles. Viral transduction was performed for 8-12 hours on NK-92 cells in the concentration of at least $5 \cdot 10^{5}$ per ml. Polybrene at a concentration of

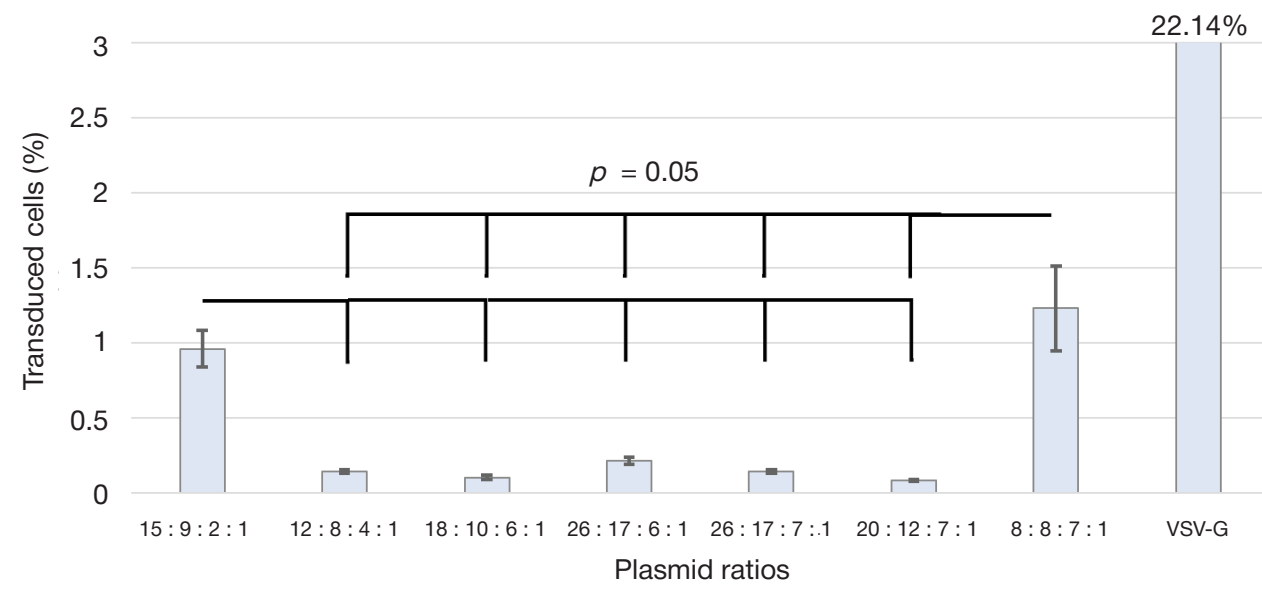

Fig. 1. The share of fluorescent HEK-293 cells, measured 48 hours post transduction by H/F-pseudotyped or VSV-G-pseudotyped lentiviral vectors. Axis X - plasmid ratios for vector:psPAX2:pMD2-F 30 :pCG-H

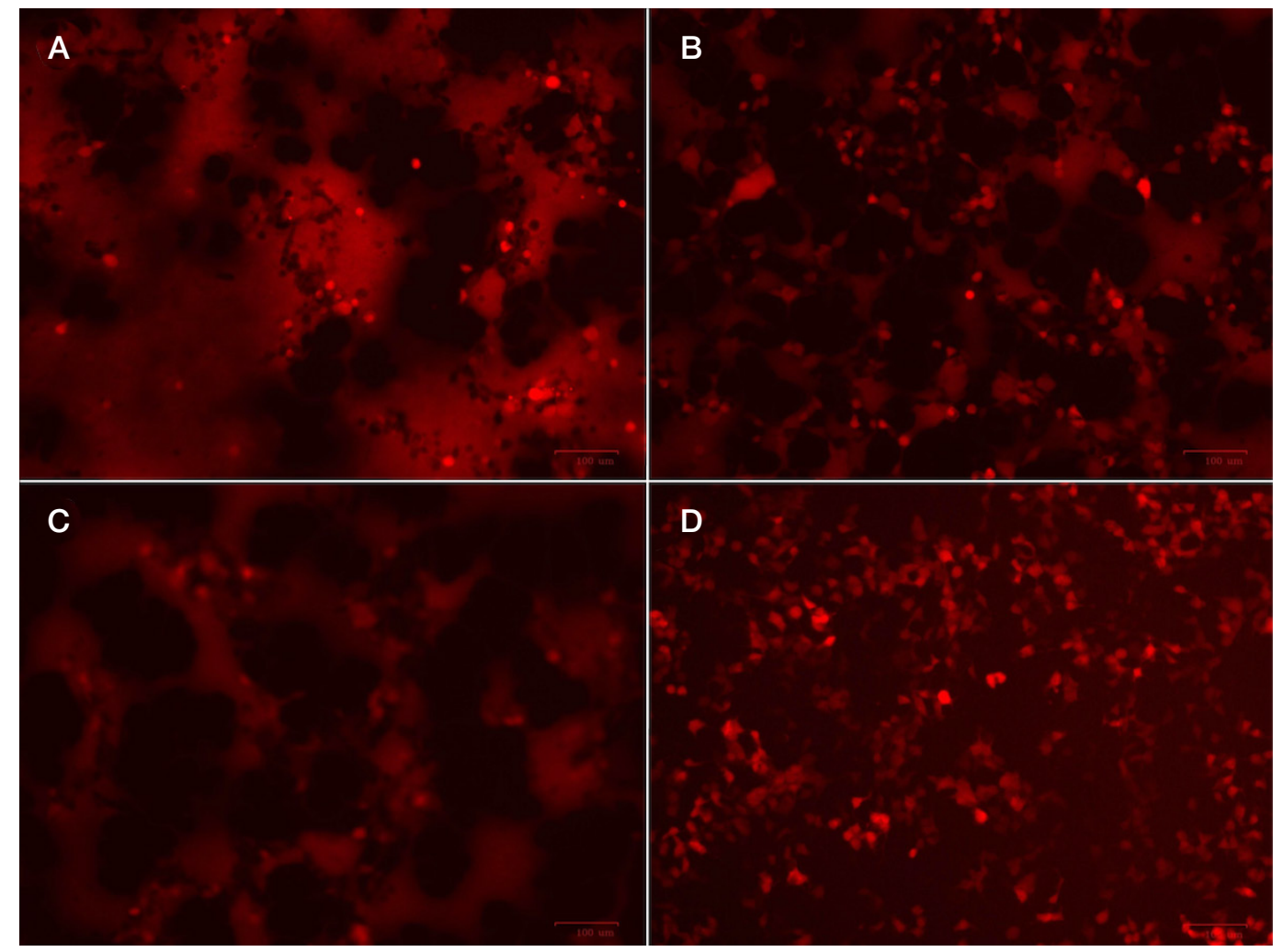

Fig. 2. Syncytia formed by HEK-293T cells after transfection with plasmid mixture for production of H/F-pseudotyped lentivirus particles. A. pCG-Hc $\triangle 18+$ pMD2-F $\triangle 30$. B. pCG-Hc $\triangle 24+$ pMD2-F $\triangle 30$. C. pCG-4A-Hc $\triangle 24+$ pMD2-F $\triangle 30$. D. pMD2-G 
$8 \mu \mathrm{g} / \mathrm{ml}$ and all required supplements for the cultivation of NK92 cells, as well as BX795 at a concentration of $3 \mu \mathrm{M}$, were added to the medium containing the virus upon infection. After transduction, the medium was replaced with complete NK-92 culture medium. The result of the transduction was assesed after 48 hours. Infectious viral titers and transduction efficiency were determined using a flow cytometer by evaluating the tagRFP positive fraction.

\section{Cytotoxicity assay}

To assess cytotoxicity, NK-92 cells were mixed with Raji cells expressing GFP in different ratios. After co-cultivation for 48 hours, the proportion and number of GFP positive cells were assessed on a flow cytometer.

\section{RESULTS}

\section{Determination of the optimal ratio of packaging plasmids}

To assess the efficiency of transduction of NK-92 cells, preparations of lentiviral vector particles pseudotyped with
VSV G-protein or three different variants of measles virus $\mathrm{H}$ protein in combination with $\mathrm{F}$ protein ( $\mathrm{H} / \mathrm{F}$ pseudotyped) were used. Several authors reported controversial information on the optimal ratio of packaging plasmids, required to obtain highest viral titers [15-19]. The known ratios as well as the ratios extrapolated from the VSV-G pseudotyped lentiviral vectors used for packaging $(5: 3: 2$ for the vector : psPAX2: pMD2-G) were used to repare lentiviral stocks and then determine infectious titers (Fig. 1). Results showed that plasmid ratios of $8: 8: 7: 1$ and $15: 9: 2: 1$ for the pLCMVtagRFP-puro : psPAX2 : pMD2-Fd30 : pCG-H $\triangle 18$ vectors showed the most efficient packaging of lentiviral particles for the $\mathrm{H}$ protein variant $\triangle 18$. For all further experiments, the ratio $8: 8: 7: 1$ was used.

Table. Infectious viral titers of viral stocks, produceB with different variants of $\mathrm{H}$ protein. All values were calculated per $10^{6}$ packaging cells

\begin{tabular}{|l|c|c|}
\hline & HEK-293 & NK-92 \\
\hline$H \triangle 18 / F \Delta 30$ & $\sim 6.15 \cdot 10^{4}$ & $\sim 2.1 \cdot 10^{4}$ \\
\hline $\mathrm{H} \Delta 24 / \mathrm{F} \Delta 30$ & $<2 \cdot 10^{2}$ & $<2 \cdot 10^{2}$ \\
\hline $4 \mathrm{~A}-\mathrm{H} \Delta 24 / \mathrm{F} \Delta 30$ & $\sim 4.3 \cdot 10^{4}$ & $\sim 1.6 \cdot 10^{4}$ \\
\hline VSV-G & $\sim 1.1 \cdot 10^{6}$ & $\sim 3.5 \cdot 10^{3}$ \\
\hline
\end{tabular}

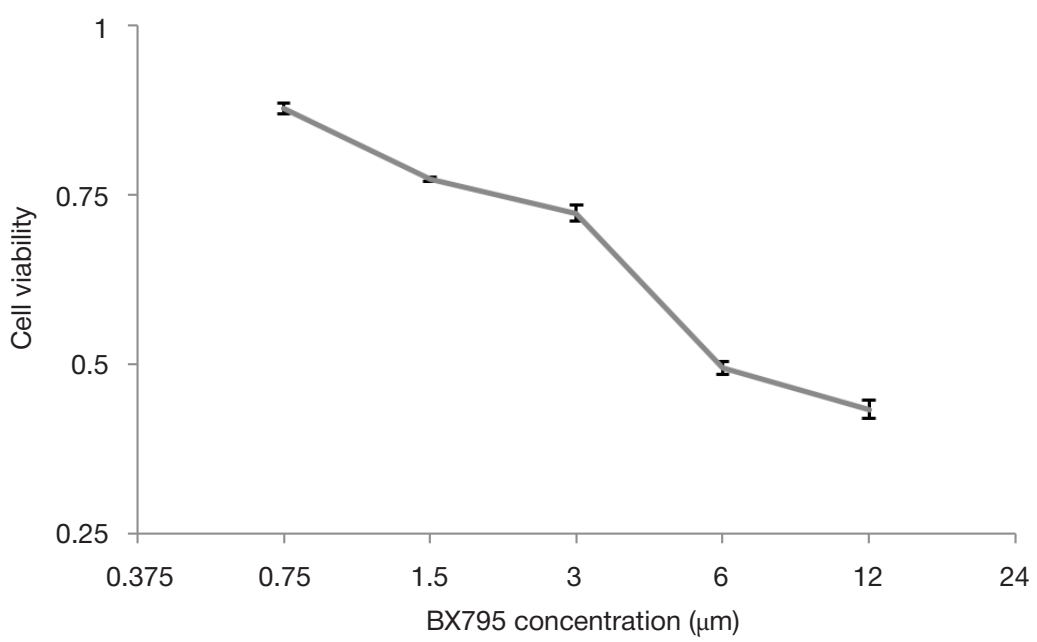

Fig. 3. Proliferative activity of NK-92 cells, measured 48 hours post addition of different amounts of BX795 to the cultivation media. All values were normalized relative to control (untreated culture). Values below 0.5 are characteristic to the culture that wasn't proliferating after addition of BX795

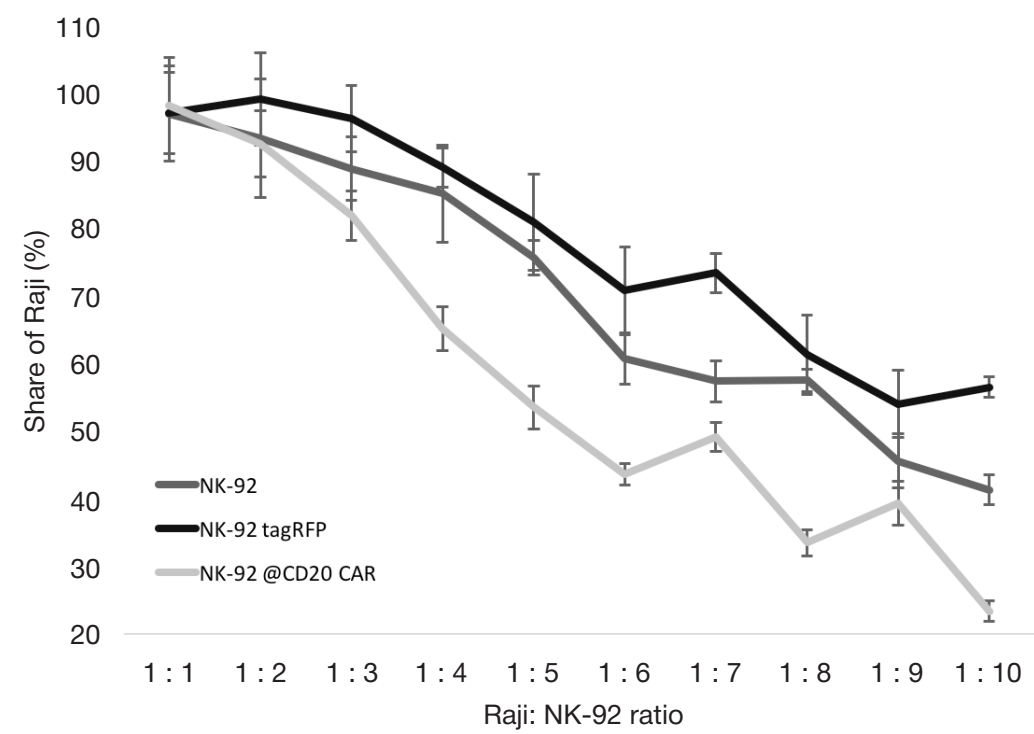

Fig. 4. Suppression of proliferation of Raji cells upon co-culturing with NK-92 cells. Axis Y - \% of Raji with normal phenotype (FSC/SSC) after 2 days of co-culturing, compared to control sample (no NK-92 addition). Series: non-transduced NK-92; NK-92, transduced by tagRFP expressor (non-selected); NK-92, transduced by CAR @CD20 after selection on magnetic microspheres 


\section{Comparison of variants of protein $\mathrm{H}$}

A characteristic feature of pseudotyping with $\mathrm{H} / \mathrm{F}$ proteins is the formation of syncytia in the culture of packaging cells. The length of the cytoplasmic tails of proteins $\mathrm{H}$ and $\mathrm{F}$ directly affects the intensity of this process, and the lesser syncytia is formed, the longer the packaging cells may be used to collect lentiviral supernatants. Excessive truncation of the cytoplasmic tails leads to a sharp drop in the infectious titers. The founding work on this topic reports that the variant of the $\mathrm{H} \Delta 18$ protein in combination with the $\mathrm{F} \Delta 30$ protein produces lentiviral vector stocks with highest transfection titer, while shortening to $\mathrm{H} \triangle 24$ almost completely suppresses the production of the infectious virus, and the addition of four alanine residues at the $\mathrm{N}$-terminus of a $\mathrm{H} \triangle 24$ mutant restores viral titers to maximum values [16]. In another work, researchers used the $\mathrm{H} \Delta 24$ protein variant to produce highly concentrated lentiviral stocks [15]. The results of our comparison of three variants of protein $\mathrm{H}$ showed that the size and rate of syncytium formation is maximum for the variant of protein $\mathrm{H} \triangle 18$, significantly lower for variant $4 \mathrm{~A}$ $\mathrm{H} \triangle 24$, and is minimal for $\mathrm{H} \triangle 24$ (Fig. 2); the transfection titer was also maximal for the $\mathrm{H} \triangle 18$ variant; however, for the $4 \mathrm{~A}$ $\mathrm{H} \triangle 24$ variant, the resulting transfection titer was only slightly inferior to the $\mathrm{H} \triangle 18$ variant, and for the $\mathrm{H} \triangle 24$ variant it was at least 2 orders of magnitude lower than the $\mathrm{H} \Delta 18$ variant. In further experiments, lentiviral particles pseudotyped by $\mathrm{H} \triangle 18$ / F $\triangle 30$ proteins were used. When measured on HEK-293 cells, the average viral titer of $\mathrm{H} / \mathrm{F}$ pseudotyped lentiviral stocks was 15-20 times lower than for lentiviruses, pseudotyped with VSV G-protein (Table).

\section{Optimization of NK-92 cell transduction conditions}

The use of VSV-G-pseudotyped lentivirus vectors for transduction of NK-92 cells showed that addition of over $\sim 10^{5}$ i.u. per $\mathrm{ml}$ of medium for 8 hours leads to a significant drop in the viability of the culture. In addition, NK-92 cells were much less efficiently transduced by VSV-G-pseudotyped lentiviruses, the difference in transfection titer compared to HEK-293 was more than 3 orders of magnitude. To increase the efficiency of natural killer transduction, the use of the TBK1/IKK $\varepsilon$ inhibitor BX795 at a concentration of 6-8 $\mu \mathrm{M}$ has been described [20]. Evaluation of the effect of BX795 on the viability of NK-92 cells showed that they retain their viability at concentrations up to $3 \mu \mathrm{M}$ (Fig. 3). BX795 allowed to reduce the difference in the transduction efficiency of VSV-G-pseudotyped viral particles up to 300-fold. Under the same transduction conditions, H/F pseudotyped lentiviral vectors were able to transduce NK-92 cells with three times less efficacy than HEK-293 cells.

\section{Evaluation of the cytotoxic effect of CAR-expressing NK-92 cells}

Since NK-92 cells require to be cultivated in high densities in order to maintain proliferative activity, the tolerable cell:i.u. ratios did not allow to obtain sufficiently high percentage of transduced cells. Isolation of the tagRFP-expressing populations by FASC made it possible to obtain small fractions of CAR-expressing cells, however, the stress incurred by the sorting procedure led to significant loss of viability. To circumvent this problem, we performed sorting of CAR-expressing cells on magnetic particles coated with monoclonal antibodies to DYKDDDDK epitope. This approach turned out to be more gentle and did not lead to suppression of proliferation of NK-92 cells. CARexpressing cells obtained with this method were tested for their ability to inhibit growth of CD20+ GFP-expressing Raji cells (Burkitt's lymphoma). Compared to unmodified cells, @CD20NK-92 were able to suppress proliferation of Raji cells in lower dosages (Fig. 4).

\section{DISCUSSION}

When comparing different variants of $\mathrm{H}$ glycoproteins, we found that shortening the cytoplasmic tail by more than 20 amino acids is impractical because of the strong decrease in transfection titers. H/F pseudotyped lentiviral particles showed significantly lower packing efficiency compared to lentiviral particles pseudotyped with VSV G-protein, but this factor was compensated by greater efficiency of transduction of NK92 cells. We noted that infection with $\mathrm{H} / \mathrm{F}$ pseudotyped viral vectors leads to less significant suppression of proliferation of NK-92 cells, which allows to use of higher concentrations of viral particles for transduction, leading to an additional increase in efficiency. It is also noteworthy that with respect to NK-92 cells, BX795 was found to be active in lower concenrations than during transduction of primary cultures. In general, the use of a combination of $\mathrm{H} / \mathrm{F}$-pseudotyped lentiviral vectors, BX795 and subsequent sorting of transduced cells on magnetic microspheres allowed us to consistently obtain populations of CAR-expressing NK-92, that demonstrated high levels of cytotoxicity against antigen-expressing target cells.

NK-92 cells are distinguished by their sensitivity for cultivation conditions and, as the experiments have shown, they are more resistant to transduction with lentiviral vectors. However, these difficulties associated with the production of NK-92 CARexpressing cells can later be compensated by the greater versatility of their applications for cellular immunotherapy, or as components of complex therapeutic approaches, for example, as carrier cells for the delivery of oncolytic viruses.

\section{CONCLUSIONS}

The results of the study showed that the optimal variant of the $\mathrm{H}$ protein of the measles virus for producing of $\mathrm{H} / \mathrm{F}$ pseudotyped lentivirus vectors is $H \Delta 18$ (in terms of transfection titer) and $4 \mathrm{~A}-\mathrm{H} \triangle 24$ (in terms of the duration of production of viral particles), the largest transfection titers were achieved using a plasmid ratio of $8: 8: 7: 1$. The resulting preparations of H/F-pseudotyped lentiviral particles had 15-20 times lower transfection titer, compared with VSV-G-pseudotyped, while in the transduction of NK-92 cells the difference in titers was $5: 1$ towards for H/F-pseudotyped virus vectors. The optimal concentration of the inhibitor TBK1/IKK $\mathrm{BX} 795$ was $3 \mu \mathrm{M}$, the use of BX795 allowed to increase the transduction efficiency by $\sim 3$ times. Transduced CAR-NK-92 cells were successfully isolated by magnetic separation and were highly capable of inhibiting the proliferation of CD20-positive Raji cells. 
1. Restifo NP, Dudley ME, Rosenberg SA. Adoptive immunotherapy for cancer: harnessing the T cell response. Nat Rev Immunol. 2012; 12 (4): 269-81. DOI: 10.1038/nri3191. PubMed PMID: 22437939

2. Zah E, Lin MY, Silva-Benedict A, Jensen MC, Chen YY. T Cells Expressing CD19/CD20 Bispecific Chimeric Antigen Receptors Prevent Antigen Escape by Malignant B Cells. Cancer immunology research. 2016; 4 (6): 498-508. DOI: 10.1158/2326-6066.CIR15-0231. PubMed PMID: 27059623.

3. Olden BR, Cheng Y, Yu JL, Pun SH. Cationic polymers for nonviral gene delivery to human T cells. J Control Release. 2018; (282): 140-7. DOI: 10.1016/j.jconrel.2018.02.043. PubMed PMID: 29518467

4. Zhang Z, Qiu S, Zhang X, Chen W. Optimized DNA electroporation for primary human T cell engineering. BMC Biotechnol. 2018; 18 (1): 4. DOI: 10.1186/s12896-018-0419-0. PubMed PMID: 29378552.

5. Tumaini B, Lee DW, Lin T, Castiello L, Stroncek DF, Mackall C et al. Simplified process for the production of anti-CD19-CARengineered T cells. Cytotherapy. 2013; 15 (11): 1406-15. DOI: 10.1016/j.jcyt.2013.06.003. PubMed PMID: 23992830.

6. Yagita M, Huang $\mathrm{CL}$, Umehara $\mathrm{H}$, Matsuo $\mathrm{Y}$, Tabata R, Miyake $\mathrm{M}$ et al. A novel natural killer cell line (KHYG-1) from a patient with aggressive natural killer cell leukemia carrying a p53 point mutation. Leukemia. 2000; 14 (5): 922-30. PubMed PMID: 10803526

7. Gong JH, Maki G, Klingemann HG. Characterization of a human cell line (NK-92) with phenotypical and functional characteristics of activated natural killer cells. Leukemia. 1994; 8 (4): 652-8. PubMed PMID: 8152260.

8. Matsuo Y, Drexler HG. Immunoprofiling of cell lines derived from natural killer-cell and natural killer-like T-cell leukemia-lymphoma. Leuk Res. 2003; 27 (10): 935-45. PubMed PMID: 12860014.

9. Klingemann HG, Wong E, Maki G. A cytotoxic NK-cell line (NK92) for ex vivo purging of leukemia from blood. Biol Blood Marrow Transplant. 1996; 2 (2): 68-75. PubMed PMID: 9118301.

10. Zhang J, Sun R, Wei H, Zhang J, Tian Z. Characterization of interleukin-15 gene-modified human natural killer cells: implications for adoptive cellular immunotherapy. Haematologica. 2004; 89 (3): 338-47. PubMed PMID: 15020274.

11. Chen Y, You F, Jiang L, Li J, Zhu X, Bao Y et al. Gene-modified NK-92Ml cells expressing a chimeric CD16-BB-zeta or CD64BB-zeta receptor exhibit enhanced cancer-killing ability in combination with therapeutic antibody. Oncotarget. 2017; 8 (23): 37128-39. DOI: 10.18632/oncotarget.16201. PubMed PMID: 28415754

\section{Литература}

1. Restifo NP, Dudley ME, Rosenberg SA. Adoptive immunotherapy for cancer: harnessing the T cell response. Nat Rev Immunol. 2012; 12 (4): 269-81. DOI: 10.1038/nri3191. PubMed PMID: 22437939

2. Zah E, Lin MY, Silva-Benedict A, Jensen MC, Chen YY. T Cells Expressing CD19/CD20 Bispecific Chimeric Antigen Receptors Prevent Antigen Escape by Malignant B Cells. Cancer immunology research. 2016; 4 (6): 498-508. DOI: 10.1158/2326-6066.CIR15-0231. PubMed PMID: 27059623

3. Olden BR, Cheng Y, Yu JL, Pun SH. Cationic polymers for nonviral gene delivery to human T cells. J Control Release. 2018; (282): 140-7. DOI: 10.1016/j.jconrel.2018.02.043. PubMed PMID: 29518467

4. Zhang Z, Qiu S, Zhang X, Chen W. Optimized DNA electroporation for primary human T cell engineering. BMC Biotechnol. 2018; 18 (1): 4. DOI: 10.1186/s12896-018-0419-0. PubMed PMID: 29378552

5. Tumaini B, Lee DW, Lin T, Castiello L, Stroncek DF, Mackall C et al. Simplified process for the production of anti-CD19-CAR-
12. Suck G, Odendahl M, Nowakowska P, Seidl C, Wels WS, Klingemann HG et al. NK-92: an 'off-the-shelf therapeutic' for adoptive natural killer cell-based cancer immunotherapy. Cancer Immunol Immunother. 2016; 65 (4): 485-92. DOI: 10.1007/ s00262-015-1761-x. PubMed PMID: 26559813.

13. Boissel L, Betancur M, Lu W, Wels WS, Marino T, Van Etten RA et al. Comparison of mRNA and lentiviral based transfection of natural killer cells with chimeric antigen receptors recognizing lymphoid antigens. Leuk Lymphoma. 2012; 53 (5): 958-65. DOI: 10.3109/10428194.2011.634048. PubMed PMID: 22023526.

14. Humbert JM, Frecha C, Amirache Bouafia F, N'Guyen TH, Boni S, Cosset FL et al. Measles virus glycoprotein-pseudotyped lentiviral vectors are highly superior to vesicular stomatitis virus $G$ pseudotypes for genetic modification of monocyte-derived dendritic cells. J Virol. 2012; 86 (9): 5192-203. DOI: 10.1128/ JVI.06283-11. PubMed PMID: 22345444.

15. Frecha C, Costa C, Negre D, Gauthier E, Russell SJ, Cosset FL et al. Stable transduction of quiescent $T$ cells without induction of cycle progression by a novel lentiviral vector pseudotyped with measles virus glycoproteins. Blood. 2008; 112 (13): 4843-52. DOI: 10.1182/blood-2008-05-155945. PubMed PMID: 18812471.

16. Funke S, Maisner A, Muhlebach MD, Koehl U, Grez M, Cattaneo R et al. Targeted cell entry of lentiviral vectors. Mol Ther. 2008; 16 (8): 1427-36. DOI: 10.1038/mt.2008.128. PubMed PMID: 18578012.

17. Kneissl S, Abel T, Rasbach A, Brynza J, Schneider-Schaulies J, Buchholz CJ. Measles virus glycoprotein-based lentiviral targeting vectors that avoid neutralizing antibodies. PLOS ONE. 2012; 7 (10): e46667. DOI: 10.1371/journal.pone.0046667. PubMed PMID: 23071609

18. Ou W, Marino MP, Suzuki A, Joshi B, Husain SR, Maisner A et al. Specific targeting of human interleukin (IL)-13 receptor alpha2positive cells with lentiviral vectors displaying IL13. Human gene therapy methods. 2012; 23 (2): 137-47. DOI: 10.1089/ hgtb.2012.054. PubMed PMID: 22612657.

19. Marino MP, Panigaj M, Ou W, Manirarora J, Wei CH, Reiser J. A scalable method to concentrate lentiviral vectors pseudotyped with measles virus glycoproteins. Gene Ther. 2015; 22 (3): 280-5. DOI: 10.1038/gt.2014.125. PubMed PMID: 25608718.

20. Sutlu T, Nystrom S, Gilliam M, Stellan B, Applequist SE, Alici E. Inhibition of intracellular antiviral defense mechanisms augments lentiviral transduction of human natural killer cells: implications for gene therapy. Hum Gene Ther. 2012; 23 (10): 1090-100. DOI: 10.1089/hum.2012.080. PubMed PMID: 22779406.

engineered T cells. Cytotherapy. 2013; 15 (11): 1406-15. DOI: 10.1016/j.jcyt.2013.06.003. PubMed PMID: 23992830.

6. Yagita M, Huang CL, Umehara H, Matsuo Y, Tabata R, Miyake M et al. A novel natural killer cell line (KHYG-1) from a patient with aggressive natural killer cell leukemia carrying a p53 point mutation. Leukemia. 2000; 14 (5): 922-30. PubMed PMID: 10803526.

7. Gong JH, Maki G, Klingemann HG. Characterization of a human cell line (NK-92) with phenotypical and functional characteristics of activated natural killer cells. Leukemia. 1994; 8 (4): 652-8. PubMed PMID: 8152260

8. Matsuo Y, Drexler HG. Immunoprofiling of cell lines derived from natural killer-cell and natural killer-like T-cell leukemia-lymphoma. Leuk Res. 2003; 27 (10): 935-45. PubMed PMID: 12860014.

9. Klingemann HG, Wong E, Maki G. A cytotoxic NK-cell line (NK92) for ex vivo purging of leukemia from blood. Biol Blood Marrow Transplant. 1996; 2 (2): 68-75. PubMed PMID: 9118301.

10. Zhang J, Sun R, Wei H, Zhang J, Tian Z. Characterization of interleukin-15 gene-modified human natural killer cells: implications 
for adoptive cellular immunotherapy. Haematologica. 2004; 89 (3): 338-47. PubMed PMID: 15020274

11. Chen Y, You F, Jiang L, Li J, Zhu X, Bao Y et al. Gene-modified NK-92Ml cells expressing a chimeric CD16-BB-zeta or CD64BB-zeta receptor exhibit enhanced cancer-killing ability in combination with therapeutic antibody. Oncotarget. 2017; 8 (23): 37128-39. DOI: 10.18632/oncotarget.16201. PubMed PMID: 28415754 .

12. Suck G, Odendahl M, Nowakowska P, Seidl C, Wels WS, Klingemann HG et al. NK-92: an 'off-the-shelf therapeutic' for adoptive natural killer cell-based cancer immunotherapy. Cancer Immunol Immunother. 2016; 65 (4): 485-92. DOI: 10.1007/ s00262-015-1761-x. PubMed PMID: 26559813.

13. Boissel L, Betancur M, Lu W, Wels WS, Marino T, Van Etten RA et al. Comparison of mRNA and lentiviral based transfection of natural killer cells with chimeric antigen receptors recognizing lymphoid antigens. Leuk Lymphoma. 2012; 53 (5): 958-65. DOl: 10.3109/10428194.2011.634048. PubMed PMID: 22023526.

14. Humbert JM, Frecha C, Amirache Bouafia F, N'Guyen TH, Boni S, Cosset FL et al. Measles virus glycoprotein-pseudotyped lentiviral vectors are highly superior to vesicular stomatitis virus $G$ pseudotypes for genetic modification of monocyte-derived dendritic cells. J Virol. 2012; 86 (9): 5192-203. DOI: 10.1128/ JVI.06283-11. PubMed PMID: 22345444.

15. Frecha C, Costa C, Negre D, Gauthier E, Russell SJ, Cosset FL et al. Stable transduction of quiescent $T$ cells without induction of cycle progression by a novel lentiviral vector pseudotyped with measles virus glycoproteins. Blood. 2008; 112 (13): 4843-52. DOI: 10.1182/blood-2008-05-155945. PubMed PMID: 18812471.

16. Funke S, Maisner A, Muhlebach MD, Koehl U, Grez M, Cattaneo R et al. Targeted cell entry of lentiviral vectors. Mol Ther. 2008; 16 (8): 1427-36. DOI: 10.1038/mt.2008.128. PubMed PMID: 18578012.

17. Kneissl S, Abel T, Rasbach A, Brynza J, Schneider-Schaulies J, Buchholz CJ. Measles virus glycoprotein-based lentiviral targeting vectors that avoid neutralizing antibodies. PLoS ONE. 2012; 7 (10): e46667. DOl: 10.1371/journal.pone.0046667. PubMed PMID: 23071609.

18. Ou W, Marino MP, Suzuki A, Joshi B, Husain SR, Maisner A et al. Specific targeting of human interleukin (IL)-13 receptor alpha2positive cells with lentiviral vectors displaying IL13. Human gene therapy methods. 2012; 23 (2): 137-47. DOI: 10.1089/ hgtb.2012.054. PubMed PMID: 22612657.

19. Marino MP, Panigaj M, Ou W, Manirarora J, Wei CH, Reiser J. A scalable method to concentrate lentiviral vectors pseudotyped with measles virus glycoproteins. Gene Ther. 2015; 22 (3): 280-5. DOI: 10.1038/gt.2014.125. PubMed PMID: 25608718.

20. Sutlu T, Nystrom S, Gilljam M, Stellan B, Applequist SE, Alici E. Inhibition of intracellular antiviral defense mechanisms augments lentiviral transduction of human natural killer cells: implications for gene therapy. Hum Gene Ther. 2012; 23 (10): 1090-100. DOI: 10.1089/hum.2012.080. PubMed PMID: 22779406. 